\title{
Fundamentos de la aplicación de películas delgadas de dióxido de vanadio como posibles componentes de ventanas inteligentes
}

\author{
Fundamentals of vanadium dioxide thin films as possible \\ components of intelligent windows
}

Fecha de recepción: 24-IX-98

Fecha de aceptación: 10-XII-98

Z.P.WU, I. NASHIYAMA y H.NARAMOTO japan Atomic Energy Research Institute

Fecha de aceptacion: $10-X 11-98$

JAPÓN

\section{RESUMEN}

En este artículo se revisan las investigaciones realizadas en películas delgadas de dióxido de vanadio que pueden ser usadas en componentes de ventanas inteligentes,

incluyendo las propiedades básicas del $\mathrm{VO}_{2}$, tales como su estructura de bandas, modelo energético de tipo electrónico y el origen del fenómeno de la transición: metal-aislador (MIT en la literatura inglesa) que constituye la base de las aplicaciones de estas películas. Finalmente, los problemas que hay en la investigación actual de este tipo de peliculas, asi como sus posibles aplicaciones en ventanas inteligentes de tipo termocrómico, se discuten brevemente.

\section{SUMMARY}

In this paper, the research on the vanadium dioxide thin film, which can be used as intelligent windows, is reviewed, including the basic properties of $\mathrm{VO}_{2}$, energy band structure, model of electronic energy and the origin of metal-to-insulator transition (MIT). Finally, the problems existing in the research and the possibility of application for $\mathrm{VO}_{2}$ as an intelligent thermochromic window are briefly discussed.

\section{INTRODUCCIÓN}

Desde la publicación pionera del trabajo experimental de Morín en 1959 [1], quien descubrió el fenómeno de la transición metal - aislador (MIT en la literatura en inglés) y los cambios bruscos de las propiedades ópticas y eléctricas a que da lugar en el dióxido de vanadio $\left(\mathrm{VO}_{2}\right)$, este material ha sido estudiado con gran intensidad por numerosos investigadores, no solamente por el interés en explorar el mecanismo de dicha

\section{INTRODUCTION}

Since the pioneering work of Morin as early as 1959 [1], who discovered metal-to-insulator transition (MIT) and abrupt changes of the optical and electrical properties in vanadium dioxide $\left(\mathrm{VO}_{2}\right)$, this material has been extensively investigated, not only by the attraction of exploring the mechanism of MIT, but also by the interests in its wide range of potential applications, such as thermochromic intelligent 
transición MIT, sino también por el gran interés en su amplia gama de aplicaciones potenciales, tales como ventanas inteligentes termocrómicas, en interruptores rápidos y diversos tipos de sensores [2-5]. El carácter mixto del ión vanadio da lugar a un número extenso de fases y compuestos posibles, que existen generalmente en forma de $\mathrm{V}_{\mathrm{n}} \mathrm{O}_{2 n+1}$ (fase Wadsley) ó $\mathrm{V}_{\mathrm{n}} \mathrm{O}_{2 \mathrm{n}-1}$ (fase Magneti), así como $\mathrm{VO}_{2}, \mathrm{~V}_{2} \mathrm{O}_{3}, \mathrm{~V}_{2} \mathrm{O}_{5}, \mathrm{~V}_{6} \mathrm{O}_{13} \mathrm{y} \mathrm{V}_{3} \mathrm{O}_{7}$. Entre éstos, el $\mathrm{V}_{2} \mathrm{O}_{3}, \mathrm{~V}_{2} \mathrm{O}_{5}$ y $\mathrm{VO}_{2}$ se han investigado intensamente, especialmente para películas delgadas cristalinas de $\mathrm{VO}_{2}$, debido a sus propiedades particulares de tipo óptico y eléctrico cerca de la región en la que se produce en fenómeno de MIT. En este artículo, se dan algunas conclusiones sobre las aplicaciones de este tipo de películas después de discutir los fundamentos del fenómeno MIT.

\section{PROPIEDADES BÁSICAS DE LAS PELÍCULAS DELGADAS DE $\mathrm{VO}_{2}$}

Las propiedades básicas de las películas delgadas de $\mathrm{VO}_{2}$ parece, hasta el presente, que son debidas a las mejoras de las propiedades eléctricas y ópticas durante la transformación estructural desde la fase rutilo (conductor metálico) a la fase monoclínica (semiconductora). Generalmente, el fenómeno de tipo MIT tiene lugar a una temperatura $\left(\mathrm{T}_{\mathrm{t}}\right)$ de $68^{\circ} \mathrm{C}$. Los valores de la relación entre la resistividad de la fase semiconductora a la fase metálica (RR) y la anchura del ciclo de histéresis (HW) son $10^{5}$ y $0,1^{\circ} \mathrm{C}$, respectivamente [6]. Para las películas de $\mathrm{VO}_{2}$ los valores de RR y HW son muy sensibles a la estequiometría de la estructura cristalina, que produce dispersiones debido a las diferentes estructuras obtenidas por diferentes laboratorios.

Los valores de $T_{t}$, RR y HW para películas con un alto grado de orientación preparadas por métodos diferentes están en los intervalos $65-68^{\circ} \mathrm{C},(2-4) \times 10^{4}$ y $2-4^{\circ} \mathrm{C}$ respectivamente $[7,8]$. La transmitancia en el infrarrojo cambia desde 50 al $80 \%$ durante el efecto MIT en el caso de películas de un espesor aproximado de $200 \mathrm{~nm}$. Algunos autores toman estos parámetros como indicadores de la calidad de la película, generalmente las características de las películas delgadas son inferiores a las de los materiales masivos de monocristales. Las curvas típicas que se obtienen bajo un ciclo térmico se presentan en las Figuras 1 y 2 y 3 .

\section{ESTRUCTURA DE BANDA Y ENERGÉTICA DEL VO,}

\subsection{Modelo de Banda de Energía}

Para un sistema de un material, el comportamiento electrónico puede darse por una estructura de bandas de los niveles electrónicos que corresponden a una energía windows, fast switch and various kinds of sensors [2-5]. The mixed-valent character of vanadium ion leads to a vast number of possible compounds and phases, which exist generally in the form of $V_{n} O_{2 n+1}$ (Wadsley phase) or $V_{n} O_{2 n-1}$ (Magneti phase), such as $\mathrm{VO}_{2}, \mathrm{~V}_{2} \mathrm{O}_{3}, \mathrm{~V}_{2} \mathrm{O}_{5}, \mathrm{~V}_{6} \mathrm{O}_{13}$ and $\mathrm{V}_{3} \mathrm{O}_{7}$. Among these, the $\mathrm{V}_{2} \mathrm{O}_{3}, \mathrm{~V}_{2} \mathrm{O}_{5}$ and $\mathrm{VO}_{2}$ are investigated extensively, mainly for $\mathrm{VO}_{2}$ crystalline thin film, due to its particular optical and electrical properties near the region of MIT. In this paper, some results and conclusions are drawn and summarized from abundant literature in the research on $\mathrm{VO}_{2}$ thin film.

\section{THE BASIC PROPERTIES OF VO THIN FILMS}

Up to now, it seems clear that the bulk crystal vanadium dioxide $\mathrm{VO}_{2}$ exhibits the better electrical and optical properties during the structural transformation from the rutile (metallic) phase to the monoclinic (semiconductor) phase. Generally, the MIT takes place at the temperature $\left(T_{t}\right)$ of $68^{\circ} \mathrm{C}$. The values of the ratio of resistivity in semiconductor phase to that in metallic phase (RR) and hysteresis width $(H W)$ are $10^{5}$ and $0.1^{\circ} \mathrm{C}$, respectively [6]. For the $\mathrm{VO}_{2}$ thin films, the $\mathrm{RR}$ and $\mathrm{HW}$ are very sensitive to the stoichiometry and the crystalline structure, which causes reported data scattering because of the different sample structures from different laboratories.

The values of $T_{t}, R R$ and $H W$ for highly oriented $\mathrm{VO}_{2}$ thin films prepared by different methods are in the ranges of $65-68^{\circ} \mathrm{C},(2-4) \times 10^{4}$ and $2-4{ }^{\circ} \mathrm{C}$ respectively $[7,8]$. The infrared transmittance changes 50-80\% during the MIT for the film thickness around $200 \mathrm{~nm}$. Some authors take those parameters as indicators of the film quality, generally the characteristics of the thin films are inferior to these of bulk single crystal. The typical electrical and optical curves under temperature cicling are presented in the Figures 1, 2 and 3.

\section{THE ELECTRONIC AND ENERGY BAND STRUCTURE OF VO}

\subsection{Energy Band Model}

To a material system, the electronic behaviors can be given by a band structure of electronic energy, which can account all of the origins for electrical and optical 

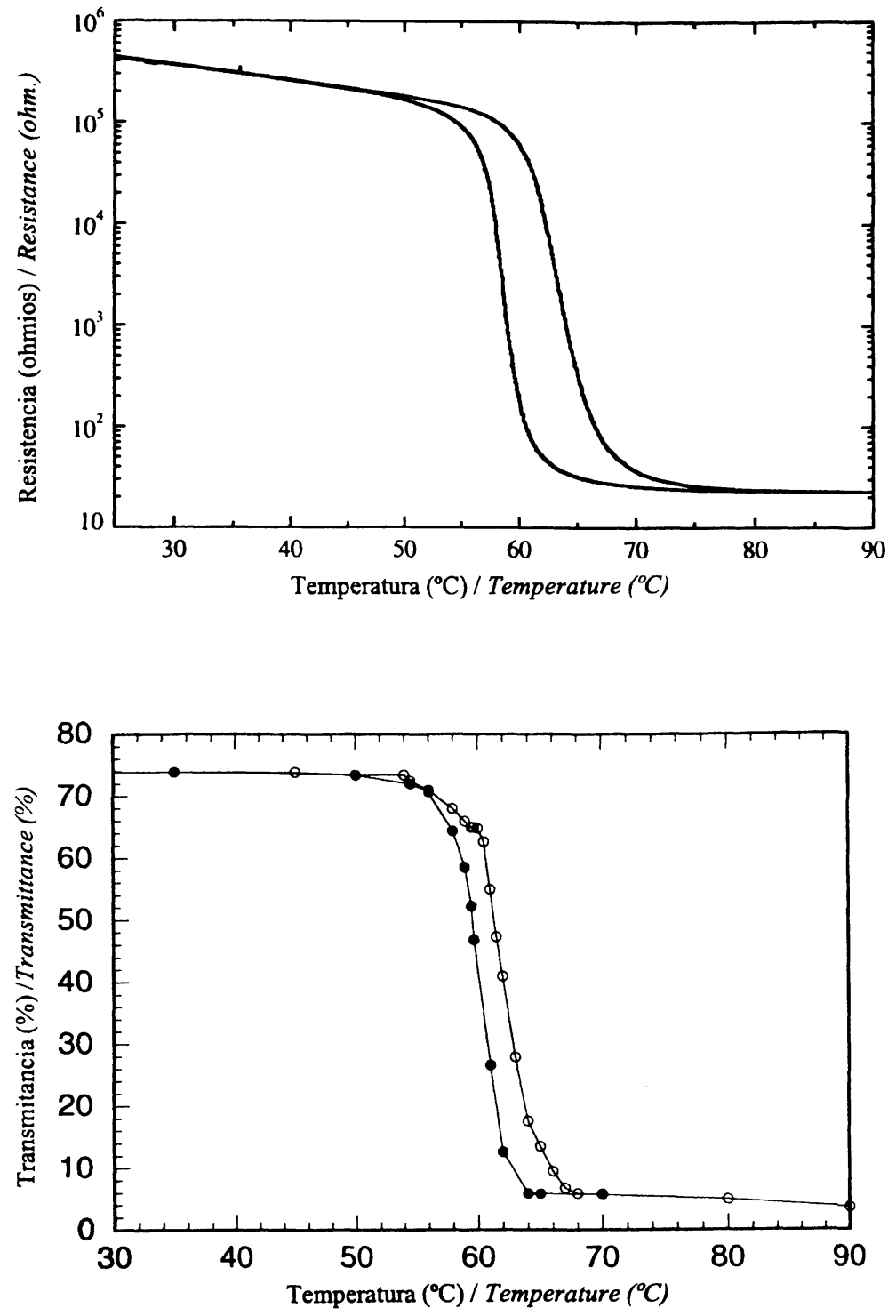

Figura 1.- Curvas típicas de la resistencia de películas delgadas $\mathrm{de} \mathrm{VO}_{2}$ con variación de la temperatura del entorno mostrando claramente la existencia de un ciclo de histéresis.

Figure 1.- The typical electric resistance of $\mathrm{VO}_{2}$ thin film under the temperature circling, where a hysteresis loop is clearly seen.

Figura 2.- Curva de transmitancia en el infrarrojo tipica del $\mathrm{VO}_{2}$ bajo un ciclo térmico desde $30^{\circ}$ a $90^{\circ} \mathrm{C}$.

Figure 2.- The typical IR transmittance curve of $\mathrm{VO}_{2}$ under temperature cicling from $30^{\circ}$ to $90^{\circ} \mathrm{C}$.

Figura 3.- Transmitancia del dióxido de vanadio depositado sobre zafiro en orientación según el eje c para un espesor de película de unos $200 \mathrm{~nm}$.

800 Figure 3.- The transmittance of vanadium dioxide on csapphire film thickness around $200 \mathrm{~nm}$. 
determinada que tienen en cuenta todas las propiedades ópticas y eléctricas del material. Debido a que el $\mathrm{VO}_{2}$ es un sistema especial y complejo, hasta el presente no hay una teoría aceptable que pueda dar una visión total y clara de la estructura de bandas energéticas, lo cual ha llevado a una frustración en la comprensión de los fenómenos investigados hasta la fecha por diversos grupos de investigación. Está claro que las bandas energéticas del $\mathrm{O}_{2 p} \mathrm{y} \mathrm{V}_{3 d}$ tienen un salto óptico de cerca de 2,5 eV para una absorción de la energía de los fonones mayores de 2,0 eV. El efecto MIT es el resultado del desdoblamiento de la banda $\mathrm{V}_{3 \mathrm{~d}}$ (metálica) con un solapamiento con la banda $\mathrm{V}_{3 \mathrm{~d}}$ (aisladora) y la banda $\mathrm{O}_{2 \mathrm{p}}$ que se mantiene sin cambios durante el transcurso del fenómeno MIT. Abbate y col. [9] han medido la espectroscopía de absorción de los rayos X para estudiar la estructura electrónica del $\mathrm{VO}_{2}$. El desdoblamiento de la banda $\mathrm{V}_{3 d}$ ha sido observado para los espectros del $\mathrm{VO}_{2}$ tomados a temperatura ambiente (fase aislante) y a $120^{\circ} \mathrm{C}$ (fase metálica).

La absorción cerca de los $0,3 \mathrm{eV}$ cuando la temperatura es inferior a la de transformación $\mathrm{T}_{\mathrm{t}}$ se cree que es debido a impurezas, imperfecciones o desviaciones de la composición de partida respecto a la estequiometría de la película. Varios autores han postulado que existe un estado fundamental para los electrones d del ión vanadio [10-12]. Lucovsky propuso un modelo de nivel localizado donde los electrones pueden ser excitados o fotoionizados desde estos niveles. El salto energético en el $\mathrm{VO}_{2}$ es de aproximadamente $0,6-0,7 \mathrm{eV}$ en el caso de la fase semiconductora, por lo que generalmente se observa la absorción de $0,3 \mathrm{eV}$. UPS en este caso es un salto de $0,2 \mathrm{eV}$ entre el nivel de Fermi y la parte superior de la banda $3 d$ [13], lo que concuerda bien con los datos de energía de activación eléctrica alrededor de $0,2-0,3 \mathrm{eV}$ en la fase semiconductora. De acuerdo con estos resultados, el diagrama de la banda energética del $\mathrm{VO}_{2}$ puede dibujarse esquemáticamente como se muestra en la Figura 4. Se puede obtener el mismo diagrama para un modelo de banda energética localizada, ya que la banda de menor energía puede considerarse como una banda localizada, compuesta de electrones d extra por ión vanadio [14-16].

\subsection{El origen del fenómeno MIT}

No es fácil de explicar cual es la fuerza que conduce el fenómeno MIT, ya que este fenómeno se acompaña, frecuentemente, con un cambio en la simetría del cristal y con la transformación de su estructura. Algunos autores suponen que se trata de un fenómeno de origen electrónico $[10,17,18]$. Los modelos teóricos desarrollados a tal efecto sugieren que por encima de la temperatura $\mathrm{T}_{\mathrm{t}}$ los electrones $3 \mathrm{~d}$ que properties of the materials. As to $\mathrm{VO}_{2}$, due to be a complicated and special system, at present, no acceptable theory can give $a$ whole and clear picture to the energy band structure, which frustrates the deep understanding to the phenomena observed in research carried out up to date. It is clear now that the $\mathrm{O}_{2 p}$ and $V_{3 d}$ energy bands with a optical gap of about $2.5 \mathrm{eV}$ account the optical absorption for the phonon energy larger than $2.0 \mathrm{eV}$. MIT is the result of the splitting in $V_{3 d}$ band from overlapped $V_{3 d}$ band(metallic phase) to splitted band (insulator) and band $\mathrm{O}_{2 p}$ which nearly keeps unchanged during MIT. Abbate et al [9] measured the soft x-ray absorption spectroscopy to study the electronic structure. The splitting of the $V_{3 d}$ band was observed from the spectra of $\mathrm{VO}_{2}$ taken at room temperature (insulator phase) and at $120^{\circ} \mathrm{C}$ (metallic phase).

The absorption near $0.3 \mathrm{eV}$ when $T<T_{t}$ is believed to be due to impurities, imperfection or composition departure from stoichiometry in the film. Several authors postulated that there exists a bound state for the extra d electron per vanadium ion [10-12]. Lucovsky proposed a localized level model where electrons can be excited or photoionized from these levels. The energy gap in $\mathrm{VO}_{2}$ is approximately 0.6$0.7 \mathrm{eV}$ in the case of semiconductor phase, because the $0.3 \mathrm{eV}$ absorption is generally observed. UPS spectra show that there is a gap of $0.2 \mathrm{eV}$ between Fermi level and the top of $3 d$ band [13], what is in well agreement with the data of electrical activation energy of about 0.2-0.3 eV in semiconductor phase. According to above results, the diagram of $\mathrm{VO}_{2}$ energy band can be schematically drawn and shown in Figure 4. The same diagram can be obtained from the localized energy band model, because the lower band generally can be regarded as a localized energy band composed of extra d electron per vanadium ion [14-16].

\subsection{The origin of MIT}

It is not easy to clarify the driving force for MIT, because the MIT are often accompanied by a change in the crystal symmetry and the structure transformation. Some authors pictured the MIT as an electronic origin $[10,17,18]$. The models suggest that above $T_{t}$, the extra $3 d$ electron derived from each $V^{4+}$ ion resides in a partially filled $d$ band giving metallic conduction. As the temperature is lowered, it 


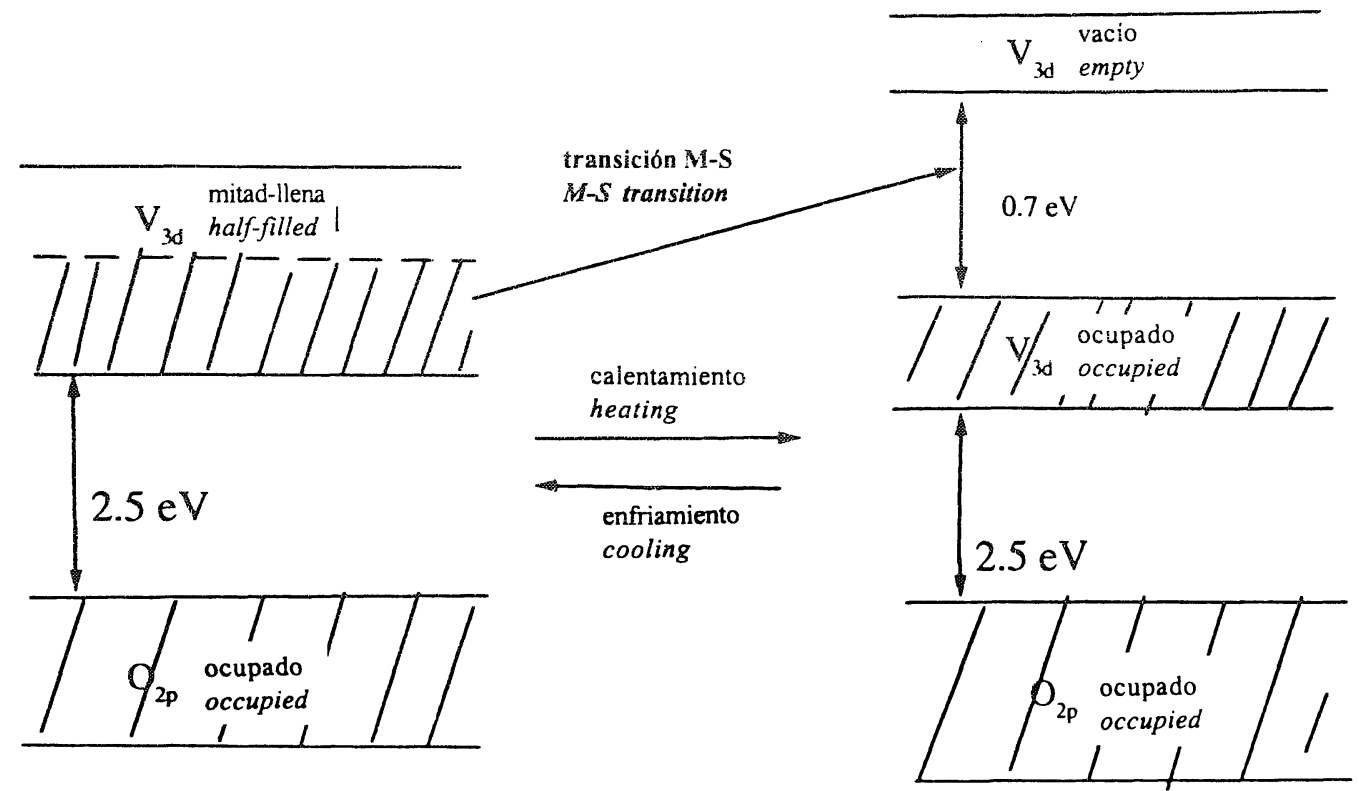

Fase metálica / Metallic phase

Fase semiconductora / Semiconductor phase

Figura 4.- Modelo de bandas de energía de la transición de fase metálica a semiconductor (MIT) en el caso del dióxido de vanadio.

Figure 4.- Energy band of metallic-semiconductor phase transition (MIT) in vanadium dioxide.

derivan de cada ion $\mathrm{V}^{4+}$ dan lugar a un llenado parcial de la banda d, produciendo una conducción de tipo metálico. Cuando la temperatura se rebaja, la estructura cristalina es más favorable energéticamente, para cambiar de la fase tetragonal a la monoclínica, dando lugar a un salto energético. Así, el $\mathrm{VO}_{2}$ tiene una estructura distorsionada con una banda separada por un salto desde una banda vacía [19]. A conclusiones similares ha llegado Goodenough [20]. El punto esencial del modelo de Goodenough es la asociación del efecto MIT con la distorsión cristalográfica derivada del cambio de la estructura de las fases. Mientras que los átomos de vanadio metálico se sitúan uniformemente espaciados a lo largo de los ejes $\mathrm{c}_{1}$ ó $\mathrm{z}$ $\left(d_{v-v}=2,85\right)$, su apareamiento como resultado de la transición conduce a la formación de dímeros de vanadio con distancias alternadas largas y cortas de enlaces $\mathrm{V}$ - V $\left(\mathrm{d}_{\mathrm{v}}=3,11 \AA, \mathrm{d}_{\mathrm{v}}=2,61 \AA\right)$ y con una distorsión de la geometría octaédrica. La reorganización subsiguiente de los niveles de energía conduce a la apertura de un salto energético de tipo semiconductor. Pero las conclusiones anteriores a veces no pueden ser aplicadas en algunos resultados experimentales obtenidos en películas delgadas de $\mathrm{VO}_{2}$ , excepto cuando se consideran los efectos de la correlación electrónica, el valor de la energía de correlación-electrón (U) puede ser tan grande como $2,1 \mathrm{eV}$ en el desdoblamiento de la banda $\mathrm{V}_{3 \mathrm{~d}}[19]$. becomes energetically favorable for the crystal structure to change from tetragonal to monoclinic and one energy gap appears. Thus, $\mathrm{VO}_{2}$ has a distorted structure, with a filled band separated by a gap from an empty band[19], similar conclusions were reached by Goodenough [20]. The essential point of the Goodenough model is the association of the MIT to the crystallographic distortion derived from the structural phase change. While in the metallic vanadium atoms are uniformly spaced along the $c_{1}$ or $z$ axis $\left(d_{v-v}=2.85 \AA\right)$; their pairing as a result of the transition leads to the formation of vanadium dimers with alternating long and short $V$ - $V$ distance $\left(d_{v}=3.11 A, d_{v}=2.61 \AA\right)$ and to the distortion of the octahedral geometry. The consequent reorganization of the energy level leads to the opening of the semiconductor gap. But the above conclusion sometimes cannot account for some experimental results in $\mathrm{VO}_{2}$ thin film, except considering the electron-correlation effects, the value of electroncorrelation energy $(U)$ can be as large as $2.1 \mathrm{eV}$ in the splitting of $V_{3 d}$ band [19]. 
Algunos autores sugieren que la red cristalina puede tener un papel crucial en el efecto MIT a través del acoplamiento fonón- electrón, debido a la gran entropía de esta transición, que no puede tenerse en cuenta sólo con la contribución electrónica. La ocurrencia de modos de fonones suaves en la fase metálica debería tenerse en cuenta, aunque el papel del llenado de los niveles energéticos del vanadio con electrones no debería ser importante [21-23].

\section{INFORMACIÓN QUE SE OBTIENE DURANTE EL EFECTOMIT}

\subsection{Potenciales aplicaciones en Arquitectura}

Hay mucha información sobre el fenómeno MIT, que hace prever que el mismo pueda tener aplicaciones interesantes en Arquitectura. Las películas delgadas de $\mathrm{VO}_{2}$ son, en realidad, materiales inteligentes (smart material)[24], con capacidad de activarse como sensores a través de la temperatura, la luz infrarroja o la luz solar, o, lo que es lo mismo, capaces de dar respuesta termocrómica. Los efectos termocrómicos tienen aplicaciones prometedoras en la modulación de la luz, en ventanas para el ahorro más eficiente de energía o en vidrios inteligentes para edificios (building glazing)[25]. Roach y Balbery [26] han encontrado que una película delgada de óxido de vanadio, iluminada con luz láser suficientemente intensa, se comporta, por un efecto de aumento de la temperatura, en un semiconductor rápido, con una transformación de fase a metal que hace que disminuya la reflectancia por un factor de 2 en la gama del visible. Se puede, por este procedimiento, alcanzar un contraste máximo de 16 cuando se aplica un revestimiento antireflectante [3]. Bugaev [27] y Becker [28] han medido la respuesta óptica de películas delgadas de este tipo en una escala de tiempo menor de los 5 picosegundos $[29,30]$. Los efectos de conexión/ desconexión (o "switching") tienen lugar en una escala muy pequeña de tiempo del orden indicado, lo que indica que pueden usarse dichas películas como medio de registro ultrarápido de información. En la región de temperatura crítica las películas de $\mathrm{VO}_{2}$ presentan una resistencia de coeficiente térmico (TCR) del $5 \%$ por grado centígrado. Para una estructura de diodo este valor alcanza $25 \%$ [31]. Este efecto es de gran interés para la detección de los cambios de temperatura bolométrica con aplicaciones en visión por infrarrojo y como termistores. Algunos autores han registrado que el cambio de fase que acompaña a este efecto produce una pequeña dilatación cercana al $0.044 \%$ [32] y una redución de la resistividad inducida por deformación [33], lo que implica que las películas de $\mathrm{VO}_{2}$ podrían usarse como "sensor de tensiones". En este sentido, se cree que con una comprensión más profunda de las
Some authors suggest that the lattice may have a crucial role in the MIT through the electron-phonon coupling, because the large entropy of the transition, which cannot account by the electron contribution only. The occurrence of soft phonon modes in the metallic phase should be taken into consideration [21-23], though the role of electron cannot be ignored.

\section{THE INFORMATIONDURINGMIT}

\subsection{The potential for applications in Architecture}

There is a lot of information during the MIT, which intrigues the research of fundamental properties of this materials, along with their numerical potential applications. $\mathrm{VO}_{2}$ thin films are taken as a smart material [24] with both sensing and actuating capabilities during its MIT induced by either temperature, infrared light or sunlight, which is also referred as thermochromism. The thermochromic effects have promising applications in thermal modulation of light, energy efficient windows or building glazing [25]. Roach and Balbery [26] found when $\mathrm{VO}_{2}$ thin film illuminated with and absorb in sufficiently intense laser light, the resulting temperature increase will induce a rapid semiconductor to metal phase transformation, its reflectance decreases about a factor of 2 through the visible range, the maximum contrast of 16 can be reached when an antireflection coating is grown [3]. Bugaev [27] and Becker [28] measured the picosecond and femtosecond optical response of $\mathrm{VO}_{2}$ thin films. The optical switching effects were reported to occur in $\mathrm{VO}_{2}$ thin film on a time scale of less than 5ps[29,30], which can be used as ultrafast information recording medium and laser switch. In the region up to critical temperature, $\mathrm{VO}_{2}$ thin films also show a temperature coefficient of resistance (TCR), 5\% per degree Celsius. For the diode structure, this value reaches 25\%[31]. This is of interest for sensitive bolometric temperature change detection with applications to infrared imager and thermistor. Some author reported that accompanying the phase change, there are a small dilation of about $0.044 \%$ [32] and a large strain induced resistivity reduction [33], implying that $\mathrm{VO}_{2}$ thin film can be used as stress sensor. We believe that with the deeper understanding of the MIT, the more information will emerge, and that makes $\mathrm{VO}_{2}$ 
causas reales del fenómeno MIT será posible controlar este efecto de una manera más eficiente y hacerle muy útil en materiales de construcción y, en concreto, en aplicaciones arquitectónicas.

\subsection{Temperatura de transición del cambio de fase (T)}

$\mathrm{T}_{\mathrm{t}}$ es el parámetro más importante en la aplicación del efecto MIT en películas delgadas de $\mathrm{VO}_{2}$, siendo un parámetro sensible a varios factores, tales como las condiciones de preparación.y la estructura de la película su grado de tensionado, presencia de impurezas, etc.

El efecto de los tipos de substrato en la $T_{t}$ puede ser atribuído a las tensiones extrínsecas desarrolladas en las capas o películas debido a la diferencia de valores del coeficiente de dilatación térmica entre las películas y el substrato. El cambio de $\mathrm{T}_{\mathrm{t}}$ hacia menores temperaturas ha sido observado en películas de $\mathrm{VO}_{2}$ y bombardeadas con $\mathrm{Ar}^{+}$, lo que se explica por la relajación de las tensiones intrínsecas en la película. Además, se ha llevado a cabo una exhaustiva investigación, en un intento de reducir la temperatura de transición por "dopado" de la composición de las películas [34-36].

Desafortunadamente, al mismo tiempo que se reduce la $\mathrm{T}_{\mathrm{t}}$, las propiedades ópticas y eléctricas se degradan también.

\subsection{Efectos de aditivos en películas delgadas de $\mathrm{VO}_{2}$}

Para reducir la $\mathrm{T}_{\mathrm{t}}$ en películas o capas de $\mathrm{VO}_{2}$, el medio más efectivo es la adición de elementos dopantes. Futaki y Aoki [34] realizaron una investigación sistemática sobre este tema. Los resultados mostraron que la temperatura de transición se rebaja o aumenta en función del aditivo empleado. La relación de $T_{\text {t }}$ con diferentes tipos de agente dopante se dan, resumidos, en la Tabla 1. more useful in building materials and several architectural applications.

\subsection{The shift of transition temperature $\left(T_{t}\right)$}

$T_{t}$ is the most important parameter for $\mathrm{VO}_{2}$ thin film, which is also a sensitive parameter to various factors, such as preparing condition and then the film structure, stress and impurities etc.

The effect of substrate types on the $T_{t}$ can be attributed to the extrinsic stress developed in the films due to the mismatch in thermal expansion coefficient between films and substrates. The shift of $T_{t}$ towards lower temperature were observed in $\mathrm{Ar}^{+}$ bombarded and porous $\mathrm{VO}_{2}$ thin films, which was explained by the release of intrinsic stress in the film. Additionally, there are a considerable amount of research performed in an attempt to reduce the transition temperature by doping [34-36].

Unfortunately, while the $T_{t}$ is reduced, the desired electrical and optical properties are somewhat degraded as well.

\subsection{Doping effects in $\mathrm{VO}_{2}$ thin films}

To reduce $\mathrm{T}_{\mathrm{t}}$ of $\mathrm{VO}_{2}$ film, the most effective way is the additive of dopant. Futaki and Aoki [34] have made a systematic research on this topic. The results show that $T_{t}$ towards either higher temperature or lower temperature can be achieved through doping. The relationship of $T_{t}$ to various kinds of dopant is summarized in Table 1.

\section{TABLA 1 (TABLE 1)}

Dependencia de $T_{t}$ con el tipo y radio ínico de aditivo empleado (The dependence of $T_{t}$ on the type and radii of dopant ions)

\begin{tabular}{|c|c|c|c|c|c|c|c|c|}
\hline $\begin{array}{c}\text { Tipo de ión } \\
\text { (lon type) }\end{array}$ & $\mathrm{Al}^{3+}$ & $\mathrm{Ti}^{4+}$ & $\mathrm{Ga}^{3+}$ & $\mathrm{Sn}^{4+}$ & $\mathrm{V}^{4+}$ & $\mathrm{Mo}^{5+}$ & $\mathrm{Nb}^{5+}$ & $\mathrm{W}^{4+}$ \\
\hline $\begin{array}{c}\text { Radio iónico (nm) } \\
\text { (lonic radius(nm)/ }\end{array}$ & 3,9 & 4,2 & 4,7 & 5,5 & 5,9 & 6,1 & 6,4 & 6,6 \\
\hline$(\mathrm{Tt}-68)^{\circ} \mathrm{C}$ & $<15$ & $<15$ & $<15$ & $<15$ & 0 & $\begin{array}{r}-23, \\
x=0,02\end{array}$ & $\begin{array}{c}-26, \\
x=0,02\end{array}$ & $\begin{array}{c}-32, \\
x=0,15(37)\end{array}$ \\
\hline
\end{tabular}


Aunque algunos autores interpretan los resultados obtenidos con la adición de $\mathrm{TiO}_{2}$ que rebaja la temperatura $T_{t}$ como un fenómeno anormal [36], se ha incluído en esta tabla con el grupo de los que incrementan la temperatura, por seguir un criterio de regularidad. La Tabla 1 muestra claramente que el cambio en la temperatura de transición es proporcional al radio del ión dopante, de manera que es mayor el incremento de la temperatura $T_{t}$ cuando el radio es más pequeño. Incluso pequeñísimas adiciones de $\mathrm{NbO}_{2}$, $\mathrm{WO}_{2} \mathrm{y} \mathrm{MoO}_{2}$, que tienen estructura monoclínica típica del $\mathrm{VO}_{2}$, disminuyen considerablemente la $\mathrm{T}_{\mathrm{t}}$. A partir de la Tabla anterior puede verse que el efecto dopante del wolframio es más efectivo que para otros tipos de aditivos. De hecho, las últimas investigaciones para reducir la $T_{t}$ están enfocadas, fundamentalmente, en el uso de este aditivo [37,38].

\section{CUESTIONES QUE SURGEN DE LA INVESTIGACIÓN CON PELÍCULAS DELGADAS DE $\mathrm{VO}_{2}$}

A partir de esta revisión se puede tener una idea general de las investigaciones en curso en láminas delgadas de $\mathrm{VO}_{2}$; sin embargo, algunos resultados, desde nuestro punto de vista, son ambiguos aún y necesitan ser comprobados en posteriores investigaciones:

a) La orientación de los granos durante el crecimiento epitáxico del $\mathrm{VO}_{2}$ y sus relaciones con el tipo de sustratos:

Algunos autores han mostrado que la orientación (0001) sobre sustratos de zafiro es la preferente para el crecimiento de cristales de $\mathrm{VO}_{2}$, aunque otros han visto que la orientación (1010) sobre el mismo tipo de sustratos es la preferida [7] dando lugar a mejores propiedades del efecto MIT, pero no se han registrado los efectos de la morfología superficial del sustrato en el crecimiento de películas de $\mathrm{VO}_{2}$. Además, las propiedades dieléctricas de los granos orientados de $\mathrm{VO}_{2}$ en los cristales sencillos de zafiro muestran una fuerte dependencia con el espesor, probablemente debido a la acumulación de tensiones por debajo de la interfase $\mathrm{VO}_{2}$-zafiro [18]. Por lo tanto, se necesita una investigación más amplia y completa para comprender el mecanismo de crecimiento, especialmente los efectos de interfase, y para aclarar las relaciones de las propiedades y orígenes del efecto MIT con la estructura de las películas.

\section{b) Respecto a los efectos de los aditivos en el $\mathrm{VO}_{2}$ :}

Es un resultado bastante aceptable, de que cuanto mayor es el radio del elemento dopante, mayor es el cambio en la temperatura de transición $\mathrm{T}_{\mathrm{t}}$, y viceversa.
Though some authors provided the results that adding $\mathrm{TiO}_{2}$ results $T_{t}$ shift towards a lower temperature as a abnormal phenomena [36], it is listed in the group towards higher temperature for the sake of regularity. Table 1 shows clearly that the shift of $T_{t}$ is conversely proportional to the dopant ionic radius, the smaller radius causes $T_{t}$ shift towards higher temperature and the larger ions causes Tt shift towards lower. Even slight amount of $\mathrm{NbO}_{2}, \mathrm{WO}_{2}$ and $\mathrm{MoO}_{2}$ are added, which take a $\mathrm{VO}_{2}$-type (monoclinic) structure, the $\mathrm{T}_{t}$ decreases considerably. From the table, the tungsten-doping effect on $T_{\text {t }}$ is more effective than any other types of dopant. In fact, recent research on reducing $T_{t}$ has mainly been focused on this doping system [37,38].

\section{QUESTIONS ARISING FROM THE RESEARCH OF VO THIN FILMS}

From the above review, one can have a general idea about the research on $\mathrm{VO}_{2}$ thin film, though much progress and good results have been achieved. However, some results, in our knowledge, are still ambiguous and need further proven.

\section{a) The grain orientation during epitaxial growth process of $\mathrm{VO}_{2}$ and its relationship to the type of substrates:}

Some authors showed the results that the (0001) substrate of sapphire is favorite to the growth of $\mathrm{VO}_{2}$ crystal, and the others reported that (1010) substrate of sapphire is better for growth of grain oriented crystalline $\mathrm{VO}_{2}$ [7] with better MIT properties, but no results have been reported so far on the effects of surface morphology of the substrate on the growth of $\mathrm{VO}_{2}$ thin films. In addition, the dielectric properties of grain oriented $\mathrm{VO}_{2}$ on single crystal sapphire exhibit strong thickness dependence, likely due to the stresses lying near the $\mathrm{VO}_{2}$-sapphire interface [18]. Therefore, the thorough and comprehensive investigation is needed to understand the growth process, especially the interface effects, to elucidate the relationship of the MIT properties to the structure of the film, as well as the origin of MIT.

\section{b) Concerns to the doping effects in $\mathrm{VO}_{2}$ :}

The acceptable result is the larger dopant ion radii results larger shift of $T_{t}$, and vice versa. It has been generally accepted that the shift of $T_{t}$ is caused by 
Se acepta generalmente que un cambio en dicha temperatura se produce por la relajación de tensiones inducidas en la propia estructura de la película. Hasta ahora no se ha registrado ningún artículo sobre el comportamiento de las impurezas después de introducirse en la red cristalina del $\mathrm{VO}_{2}$, tanto si ocupan lugares en la red o permanecen en lugares intersticiales actuando como transportadores de carga o como defectos en la red cristalina. Para responder a estas cuestiones se piensa que debe realizarse una investigación más detallada. En este sentido, en nuestro grupo de investigación se ha caracterizado recientemente el efecto del dopado sustitucional de Mo en películas delgadas cristalinas simples de $\mathrm{VO}_{2}$ [39]. Actualmente se está investigando más en esta dirección.

\section{c) Efectos de los bordes de grano en las propiedades del fenómeno MIT:}

El efecto MIT produce muchas discontinuidades o saltos energéticos en los siguientes parámetros: constantes reticulares, saltos energéticos y propiedades. Los efectos de conexión (o "switching") parcial han sido estudiados por Fillingham [40]. Las regiones cristalinas o granos en la película no pueden conectarse todas entre sí a $68^{\circ} \mathrm{C}$. Las tensiones formadas en estas pequeñas regiones son responsables, probablemente, al menos en parte, de la histéresis en las curvas de resistividad y en las curvas de transmitancia. El análisis teórico de la transmitancia durante el proceso MIT predice que la forma de la curva será más empinada si la película crece con una fase sencilla con buenas interfases de los bordes de grano. Por lo tanto, se debe dedicar mucha atención al proceso de preparación de láminas delgadas de alta calidad y a los efectos de la evolución de la microestructura durante el fenómeno MIT. Se han encontrado estructuras diferentes de maclado y polidominios de heterofases en películas de $\mathrm{VO}_{2}$ [42], pero aún no se conoce cómo estas microestructuras afectan a las propiedades del efecto MIT. Por tanto, es necesario investigar más, de modo que se controle in situ el conjunto de procesos que tienen lugar durante el efecto MIT.

d) Sobre la aplicación del $\mathrm{VO}_{2}$ en la producción de ventanas inteligentes:

Para alcanzar este objetivo, la clave está en producir el cambio de la temperatura de transformación $\left(T_{t}\right)$ a temperatura ambiente con un suficiente contraste en la transmitancia o en la reflectancia. El esfuerzo para reducir la $T_{t}$ ha sido muy grande en los últimos años, tal y como se ha comentado en el apartado 4. Aunque las propiedades eléctricas se degradan cuando se dopa el material; sin embargo, las propiedades ópticas no son the release of stress induced in the film. Up to now, no paper has reported about the behavior of the impurities after their entering $\mathrm{VO}_{2}$ crystal lattice, whether they are taking the lattice sites or staying in the interstitial, contributing carriers or acting as defects. To answer those questions, much more detailed research is needed. Recently, in our group, we have successfully characterized the substitutional doping of Mo in single crystalline $\mathrm{VO}_{2}$ thin film [39]. More detailed research is in progress.

\section{c) The effects of grain boundary on the MIT properties:}

The MIT effect, causes a lot of discontinuity or gaps, likes revolution, in the following parameters: lattice constant, energy gap and the properties. Partial switch effects have been studied by Fillingham [40]. The crystalline regions (grains) in the film may not switch all at $68^{\circ} \mathrm{C}$. The stresses built up in these small regions are probably responsible at least in part for the hysteresis in the resistivity and transmittance curves. The theoretical analysis for transmittance during MIT predicts that the shape of the curve will be more steep if the film grows with single phase with good boundary interfaces. Therefore, much attention should be paid to the preparation of high quality film and the effects of the evolution of the microstructure during MIT. Different twin structures and heterophase polydomain have been found [42] in $\mathrm{VO}_{2}$ films, but how these microstructures affect MIT properties still remains in mystery. Further study with the help of in situ monitoring the MIT processes is necessary.

\section{d) About the application of $\mathrm{VO}_{2}$ as an intelligent windows:}

To achieve this goal, the key is to shift the $T_{t}$ to ambient with sufficient transmittance or reflectance contrast. The effort for reducing $T_{t}$ has achieved great progress as introduced in section 4. Though the electrical properties are degraded upon doping, the optical properties may not be so sensitive to 
tan sensibles a los aditivos o agentes dopantes [41]. Recientemente [36,37], la investigación ha demostrado que la operatividad de las películas de $\mathrm{VO}_{2}$ como recubrimiento termocrómico es satisfactoria para una $\mathrm{T}_{\mathrm{t}}=36^{\circ} \mathrm{C}$ y con una transmitancia que cambia un $55 \%$ a $\lambda=2,5 \mu \mathrm{m}$ durante el efecto MIT. En la región del visible, los espectros parecen afectarse menos por efecto de los aditivos. En este sentido, la película de $\mathrm{VO}_{2}$ puede ser considerada como una ventana eficientemente energética, más bien que una ventana inteligente.

Finalmente, para terminar se quiere dejar constancia de la complicación implícita en la investigación del $\mathrm{VO}_{2}$, por lo que actualmente es casi imposible de dilucidar y resumir todos los aspectos relacionados con la investigación en este tipo de materiales y en campos relacionados con sus aplicaciones. Por tanto, esta revisión crítica debe ser considerada como una guía para posteriores investigaciones y futuros desarrollos de las aplicaciones de las películas de $\mathrm{VO}_{2}$.

\section{AGRADECIMIENTOS}

Se agradece al Dr. Jesús $M^{a}$ Rincón, Jefe del Lab. de Materiales Vitro- Cerámicos del Instituto E. Torroja de Ciencias de la Construcción por sus sugerencias y discusiones, así como por su ayuda en la correcta traducción de este artículo al español. dopant [41]. Recently [36,37], the research demonstrates that the performance of $\mathrm{VO}_{2}$ films as a thermochromic coating is satisfactory with $T_{t}=36^{\circ} \mathrm{C}$ and transmittance changing $55 \%$ at $\lambda=2.5 \mu \mathrm{m}$ during MIT. In visible region, the spectra seems to be less affected by doping or MIT. In this sense, $\mathrm{VO}_{2}$ may be taken as a energy efficient window rather than an intelligent window.

Finally, it would like to mention that the research on $\mathrm{VO}_{2}$ is a complicated subject that it is for the moment almost impossible to elucidate and to summarize all aspects of its related research fields. This review can be only taken as a guideline to further research for future applications and developments of $\mathrm{VO}_{2}$ thin fims.

\section{ACKNOWLEDGEMENT}

I would like to thank Dr. Jesus $M^{a}$ Rincon, Head of The Glass- Ceramics Lab., Institute E. Torroja of Constructions Science, CSIC, Spain for his kind suggestion for publication of this paper and discussions on this topic.

\section{BIBLIOGRAFÍA}

[1] MORIN, F.J. (1959): Phys.Rev.Lett.3: 34.

[2] JORGENSON, G.V., LEE, J.C. (1986): Solar Energy Mater. 14: 205.

[3] BALBERY, I., TROKMAN, S. (1975): J.Appl.Phys.46: 2111.

[4] BALDUCCI, G., GIGLI, G., GUIDO, M. (1983): J.Chem.Phys. 79: 5616.

[5] LU-S, HOU, L. AND GAN, F. (1993): J.Mater.Sci.,28: 2169.

[6] LADD, L.A., PAUL, W. (1969): Solid State Commun.7: 425.

[7] KIM,D.H.AND KWOK,H.S. (1994): Appl.Phys.Lett.,65: 3188.

[8] BOREK,M., QIAN,F., NAGABUSHNAM, V. and SINGH,R.K. (1993): Appl.Phys.Lett ,63: 3288.

[9] ABBATE, M., PEN, H., CZYZYK, M. T., GROOT, F. M. F. DE., FUGGLE, J. C., MA,M.Y, CHEN,C.T., SETTA,F., FUJIMORI,A., UEDA,Y., KOSUGE,K. (1993): J.Ele.Spec. and related Phenomena, 62:185.

[10] ADLER, D., BROOKS, H. (1969): Phys. Rev. B155:825.

[11]FROHLICH, H.(1967): Proceeding of the Symposium of Ferroelectricity (Amsterdam 1967)P6.

[12] MOTT, N. F. (1949): Proc.Phys.Soc.(London)A62: 416. 
[13] SHIN, S., SUGA, S., TAMGUCHI, M., FUJISAMA, M., KANZKI, H., FUJIMORI, A., DAIMON, H., UEDA, Y., KOSUGE, K., KACHI, S. (1990): Phys.Rev., B41:4993.

[14] FUJIMURI, A., KAWAKAMI, K., TSUDA, N. (1988): Phys.Rev.B38: 7889.

[15] KAWAKAMI, K., SAKAI, Y.,TSUDA, N. (1986): J.Phys Soc.Jpn 55:3174.

[16] MAMIYA, H., ONODA, M. (1995): Solid state Commu.95: 217.

[17] PHILIP, H. R. and RHRENREICH, H.(1963): Phys.Rev., 129:1550.

[18] HYLAND, G. J. (1968): J.Phys.C1: 189.

[19] VERLEUR, HANS W., BARKER, A. S., BERGLUND, JR. C. N. (1968): Phys. Rev., 172: 788.

[20] GOODENOUGH, J. B. (1960): Phys.Rev.117: 1442.

[21] GUPTA, M., FREEMAN, J.,ELLIS, D. E. (1977): Phys.Rev.B16 : 3338.

[22] PAUL, W. (1970): Mater.res.Bull.5 :691.

[23] SRIVASTANA, R., CHASE, L. L. (1971): Phys.Rev.lett.27:727.

[24] VARADAM, V. K. (1994): ed., Proc.SPIE2189.

[25] LAMPERT, C. M. and GRANQUIVIST, C. G. (1990): ed. Large-area chromogenis: Materials and devices for transmittance control Vol154,(SPIEOptical engineering Press, Bullingham,1990).

[26] ROACH W.R. and BALBERY, I. (1971): solid state Conmmun. 9: 551. [18] DAVID, ADLER and HARVEY, BROOKS (1967): Phys.Rev.155: 826.

[27] BUGAEV, A. A., GUDYALIS, V. V., ZAKHARCHENYAB. P., CHUDNOVSKI, F .A. (1981):JETP Letter 34:430.

[28] BECKER, M. F., BUCKMAN, A. B., WALSER, R. M. (1994): Appl.Phys.Lett.65:1507.

[29] BECHER, M.F., BUCKMAN, A. B., WALSER, R. M., LEPINE, T., GEORGES P. and BRUN, A. (1994): Proc. SPIE $2189: 400$.

[30] JEROMINEK, H., PICARD F., and VINCENT, D. (1994): Opt.Eng.32: 2092.

[31] KUZNETSOV V. A. AND HANEMAN, G. (1996): J.Appl.Phys.79 : 8109.

[32] KUCHARCZYK, D. and NIKLENWISKI, T. (1979): J.Appl.Cryst. 12:370.

[33] GREGG, J. M., BOWMAN, R. M. (1997): Appl.Phys.Lett.71: 3649.

[34] FUTAKI, H., AOKI, M. (1969): Jpn. J.Appl.Phys.8:1008.

[35] SEMENOV, A. L. (1994): Phys.Solid State 36:1079.

[36] RAO, C.N.R. et al. (1971): J.Phys.Chem.Solids, 32:1147.

[37] TAKAHASHI, I., HIBINO, M., KUDO, T. (1996): Jpn.J.Appl.Phys., 35: L438.

[38] JIN, P., NAKANO, S., TAHEMURU, S. (1998): Thin Solid Films, 324: 151.

[39] WU, Z. P., YAMAMOTO, A., MIYASHITA, S., ZHANG, Z. J., NARUMI, K., NARAMOTO, H. (1998): J.Phys.:Cond.Matt., 10: L765.

[40] FILLINGHAM, P. J. (1967): J.Appl.Phys.Lett.38: 4823.

[41] CASE, F. C.(1984): J.Vac.Sci.Technol.2: 1509. 